\title{
Potentially toxic element (PTE) levels in maize, soil, and irrigation water and health risks through maize consumption in northern Ningxia, China
}

Ping Liu ${ }^{1,2}$, Yahong Zhang ${ }^{3}$, Ningchuan Feng ${ }^{3,4}$, Meilin Zhu ${ }^{3,4^{*}}$ and Juncang Tian ${ }^{1 *}$

\begin{abstract}
Background: Industrial and agricultural activities result in elevated levels of potentially toxic elements (PTEs) in the local environment. PTEs can enter the human body through the food chain and pose severe health risks to inhabitants. In this study, PTE levels in maize, soil, and irrigation water were detected, and health risks through maize consumption were evaluated.

Methods: Maize, soil, and irrigation water samples were collected in northern Ningxia, China. Inductively coupled plasma-optical emission spectrometry was applied to determine the contents of six PTEs. Bioaccumulation factor was used to reflect the transfer potential of a metal from soil to maize. Health risks associated with maize consumption were assessed by deterministic and probabilistic estimation. Sensitivity analysis was performed to determine variables that pose the greatest effect on health risk results.

Results: The levels of Pb and $\mathrm{Cr}$ in maize exceeded the standards, while the PTE levels in soil and irrigation water did not exceed the corresponding standards. The bioaccumulation factor values of the six PTEs in maize were all lower than 1 and followed the order of $\mathrm{Cd}>\mathrm{Zn}=\mathrm{As}>\mathrm{Cr}>\mathrm{Cu}>\mathrm{Pb}$. The hazard index (0.0986) was far less than 1 for all inhabitants implying no obvious non-carcinogenic risk. The carcinogenic risk value was $3.261 \times 10^{-5}$, which was lower than the maximum acceptable level of $1 \times 10^{-4}$ suggested by United States Environmental Protection Agency (USEPA). Females were at greater risk than males, and the age group of below 20 years had the greater risk among all the groups evaluated. Approximately $0.62 \%$ of inhabitants exceeded the level for non-carcinogenic risk, while $8.23 \%$ exceeded the level for carcinogenic risk. The As concentration and daily intake of maize contributed 35.8, and 29.4\% for non-carcinogenic risk results as well as 61.0 and $18.5 \%$ for carcinogenic risk results.
\end{abstract}

Conclusions: Maize was contaminated by $\mathrm{Pb}$ and $\mathrm{Cr}$, whereas the associated soil and irrigation water were not contaminated by PTEs. Inhabitants would not suffer obvious harmful health risks through maize consumption. Arsenic level and daily intake of maize were the most sensitive factors that impact health risks.

Keywords: Potentially toxic element, Bioaccumulation, The Yellow River, Potential health risk, Monte Carlo simulation

\footnotetext{
* Correspondence: jay70281@163.com; slxtjc@163.com

${ }^{3}$ College of Pharmacy, Ningxia Medical University, Yinchuan 750004, China

${ }^{1}$ School of Civil and Hydraulic Engineering, Ningxia University, Yinchuan

750021, China

Full list of author information is available at the end of the article
}

(c) The Author(s). 2020 Open Access This article is licensed under a Creative Commons Attribution 4.0 International License, which permits use, sharing, adaptation, distribution and reproduction in any medium or format, as long as you give appropriate credit to the original author(s) and the source, provide a link to the Creative Commons licence, and indicate if changes were made. The images or other third party material in this article are included in the article's Creative Commons licence, unless indicated otherwise in a credit line to the material. If material is not included in the article's Creative Commons licence and your intended use is not permitted by statutory regulation or exceeds the permitted use, you will need to obtain permission directly from the copyright holder. To view a copy of this licence, visit http://creativecommons.org/licenses/by/4.0/. The Creative Commons Public Domain Dedication waiver (http://creativecommons.org/publicdomain/zero/1.0/) applies to the data made available in this article, unless otherwise stated in a credit line to the data. 


\section{Background}

Environmental contamination has become a serious problem in developing countries as a result of rapidly increasing population growth, industrial and commercial development, and accelerated urbanization [1]. PTEs are an important type of contaminant that can accumulate in the environment from sources such as mining, pesticides, and chemical fertilizers [2]. In China, the environment is more heavily contaminated by PTEs in regions with higher degrees of industrialization. Industrial wastes such as waste water, waste residue, and flue gas can affect the surrounding agricultural land, water, and air. In a previous study, the PTE concentration in $29.4 \%$ of soil samples collected from 2523 industrial parks exceeded the standard for soil environmental quality [3]. Due to the toxicity and persistence of toxic elements, PTEs pollution in soil were more harmful than other soil pollutants [4-6]. For example, cadmium (Cd) exposure can cause adverse health effects, including damage to the lung, liver, testicles, brain, bone, and blood system along with cancer; $\mathrm{Cd}$ can accumulate for 10 to 20 years in the human body and is considered one of the most toxic PTEs [7-9]. The main toxic effects of lead $(\mathrm{Pb})$ are neurological effects, especially intelligence quotient (I.Q.) deficits [10]. In children, Pb may cause behavioral disturbances along with learning and concentration difficulties [11]. Although arsenic (As) is a metalloid, it is considered as a metal in many studies because it behaves similar to a PTE in many aspects. When As enters the body, it is primarily deposited in the hair, bones, and other organs and can lead to disorders of the respiratory, nervous, and circulation systems along with cancer [12, 13]. Although some PTEs including copper $(\mathrm{Cu})$, zinc $(\mathrm{Zn})$, and chromium $(\mathrm{Cr})$ are considered essential micronutrients at low concentrations $[14,15]$, they can pose non-carcinogenic hazardous effects on human health when present at concentrations exceeding the tolerable doses [16].

Ningxia is a typical developing region in China. Northern Ningxia is an important industrial area that is home to several industrial parks; untreated emissions have resulted in environmental pollution in this area. In recent years, researches on the contamination status of this area have been conducted [17, 18]. Groundwater and soil in this area have been polluted to some extent by multiple PTEs. For example, the soil is seriously contaminated with $\mathrm{Cd}$, with concentrations exceeding the standard level; the concentrations of $\mathrm{Zn}, \mathrm{Pb}, \mathrm{Cu}$, and $\mathrm{Cr}$ in the soil are higher than the background values for Ningxia [18]. However, soil samples analyzed in Ref. [18] were collected from industrial parks; the surrounding agricultural soil was not evaluated. The Yellow River is the second largest river in China and provides the drinking water, domestic water, and agricultural irrigation water for the regions along the river. However, rapid population growth and industrial development have resulted in the direct discharge of pollutants into the river, including metals, causing the water quality to deteriorate [19, 20]. For example, filtered water from the Yellow River in the Ningxia area was reported to be severely polluted by $\mathrm{Cr}$ [21]. Given that crops could be strongly affected by metals in soil and irrigation water, the levels of PTEs in agricultural soil and irrigation water around an industrial area should be determined. Previous studies indicated that the physicochemical properties of the soil and irrigation water, such as $\mathrm{pH}$ and organic matter (OM) of soil, pH and salinity (usually expressed as electrical conductivity (EC)) of water, affected metal accumulation in plants [22, 23]. Therefore, important physicochemical properties of soil and irrigation water also should be analyzed.

The consumption of food grown in local fields contaminated with PTEs presents a health risk for local inhabitants [24]. Risk assessments are performed using various indices, including the hazard quotient (HQ) [25], hazard index (HI) [26], and morbidity status (MS) [27]. Although numerous studies have been carried out in some heavily polluted regions [28] or developed areas [29] of China, less attention has been paid to developing regions such as Ningxia province. Therefore, the potential health risks of PTE contamination to local inhabitants in developing regions should be evaluated.

This study was carried out in northern Ningxia, China, where the Yellow River has been used to irrigate crops for several decades. Maize (Zea mays L.) is the most widely grown crop in the study area. The objectives of this study were to (1) determine the levels of six common PTEs ( $\mathrm{Cd}, \mathrm{Pb}, \mathrm{Cr}, \mathrm{Zn}, \mathrm{Cu}$, and $\mathrm{As}$ ) in maize, associated soil, and irrigation water; (2) assess the metal accumulations ability of maize; (3) evaluate the hazardous health risks of PTEs exposure by maize consumption; and (4) calculate the most sensitive factors affecting health risks.

\section{Methods}

\section{Study area and sample collection}

The study area was located in Northern Ningxia, China, where an industrial region called "Shizuishan industrial park" operates. Approximately eight small industrial parks with more than 300 enterprises are located near this area, including metal mining, smelting and processing, petroleum, coal, and other fuel processing, electroplating, and chemical processing facilities. The surrounding soil and groundwater would be polluted by PTEs from the industrial park. The Yellow River passes through this area and water from the Yellow River is used to irrigate the surrounding agricultural fields. The population in this area is approximately 800,000 . The 
climate belongs to the warm temperate zone and maize is the major crop.

As shown in Fig. 1, 45 fresh, raw maize samples and the associated soil were collected from the cultivated area in August 2017. The sampling plot was collected randomly in the vicinity of the industrial park and the area of each sampling plot was $200 \mathrm{~m} \times 200 \mathrm{~m}$. In each plot five replicate samples were taken by five-point sampling method. The same variety of maize (general maize) was selected. Surface soil $(0-20 \mathrm{~cm})$ was collected using a wooden spatula through five-point sampling method.

The method of irrigation water sampling was referred to the national standard of NY/T396-2000 [30]. Given that not every site has irrigation water when sampling, water sample was collected when the sampling site was near the tributary of the Yellow river. Five points were suggested by the national standard. Thus, five irrigation water samples were collected from the tributary of the Yellow river near the point of maize sampling in the present study. Each water sample was collected in a polypropylene bottle, and added with $1 \mathrm{~mL}$ of concentrated nitric acid $\left(\mathrm{HNO}_{3}\right)$ to eliminate microbial activity.

The samples of maize and soil were collected by the permission of the peasant household, while irrigation water was collected without any permission. All the samples were packed, labeled and immediately transported to the laboratory.

\section{Chemical analysis}

Maize was pre-treated according to the national standard of NY/T398-2000 [31]. The samples were dried in an oven (DHG-9030A, China) at $60^{\circ} \mathrm{C}$ and powdered using a grinding mill $(0.2 \mathrm{~mm}$ sieve). The sifted samples $(0.5 \mathrm{~g})$ were weighed into digestion tubes, and added with $10 \mathrm{~mL}$ of digestion solution $\left(v: v, \mathrm{HNO}_{3}: \mathrm{HClO}_{4}=4\right.$ : 1). After cold-digestion overnight, the mixture was further digested with a block digester at $120^{\circ} \mathrm{C}$ until the solution was clear. The digested samples were then diluted to a volume of $10 \mathrm{~mL}$ with Milli-Q water. The soil samples were prepared referring to the national standard of

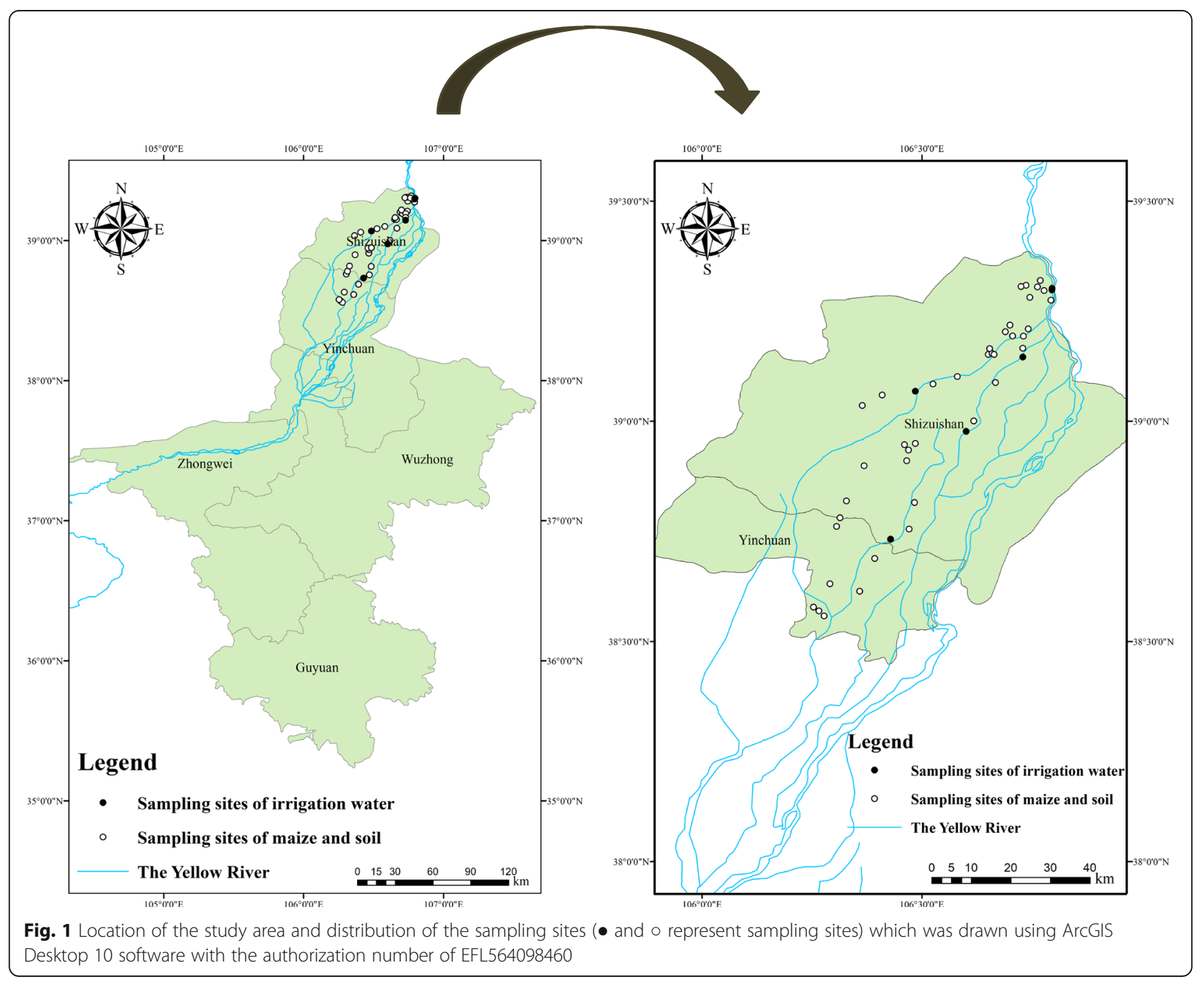


NY/T 395-2012 in China [32]. The soil was air-dried until reaching a constant weight and powdered using a grinding mill ( $0.2 \mathrm{~mm}$ sieve). Subsequently, $12 \mathrm{~mL}$ of nitric acid:hydrofluoric acid $\left(v: v, \mathrm{HNO}_{3}: \mathrm{HF}=5: 1\right)$ was added to $0.35 \mathrm{~g}$ of each soil sample in a Teflon digestion tube. The mixture was heated at $120^{\circ} \mathrm{C}$ until the solution volume reached approximately $3 \mathrm{~mL}$. The sample was then added with $5 \mathrm{~mL}$ of perchloric acid was added to continue the digestion until the solution was clear. The acid in the sample was evaporated at the same temperature until $1-2 \mathrm{~mL}$ of the solution remained. The solution was then transferred to $50 \mathrm{~mL}$ colorimetric tube and diluted to a final volume of $50 \mathrm{~mL}$ with water. Irrigation water samples were treated according to the national standard of GB 5084-2005 in China [33]. The samples were filtered with $0.45 \mu \mathrm{m}$ filters, and $20 \mathrm{~mL}$ of each filtered solution was digested with $5 \mathrm{~mL}$ of nitric acid. The digested samples were diluted to $10 \mathrm{~mL}$ with Milli-Q water.

The contents of PTEs $(\mathrm{Cd}, \mathrm{Pb}, \mathrm{Cr}, \mathrm{Zn}, \mathrm{Cu}$, and $\mathrm{As})$ were determined by ICP-OES (Varian710-ES, USA). Quality control was performed to ensure the the accuracy and precision of the experiment procedures (Table 1S). Each analysis was performed in triplicate. In each sample batch, a blank reagent, standard reference soil (GBW07419), cabbage (GBW10014), and a multi-element standard solution (GNM-M1228772013) were used when soil, maize and water were treated. The correlation coefficients of each element were $>0.9990$. The recoveries of elements ranged from 85 to $110 \%$, and the relative standard deviation (RSD) values were $<5 \%$.

Some physicochemical properties of soil and irrigation water were evaluated. Soil $\mathrm{pH}$ and organic matter (OM) were measured the laboratory according to the standard of NY/T 395-2012 in China [32]. Water pH and electrical conductivity (EC) were detected in situ according to the standard of GB 5084-2005 in China [33].

\section{Questionnaires on maize consumption}

To determine the maize consumption habits of residents, questionnaires were distributed in villages close to the sampling sites. Food frequency method was used to design the questionnaires in this study [34]. A total of 103 local inhabitants who consumed self-planted maize were selected to complete the questionnaire considering age distribution and gender balance. The questionnaire includes information about age, gender, body weight, frequency, and quantity of maize consumption, and maize source. The maize consumption information of the residents was used for health risk assessment. As experts suggested that the dietary structure of infants $(<3$ years old) is different from that of adults, infants were not considered in the current study.

\section{Health risk assessment}

\section{Deterministic assessment}

Among the six metals considered, $\mathrm{Cd}, \mathrm{Pb}, \mathrm{Cr}, \mathrm{Zn}$, and $\mathrm{Cu}$ pose non-carcinogenic health risks through oral exposure, while As poses both non-carcinogenic and carcinogenic health risks upon oral exposure. The noncarcinogenic effect of an individual metal could be evaluated by HQ value calculated using Eq. (1) [35]:

$$
\mathrm{HQ}=\mathrm{EXPO} / \mathrm{RfD},
$$

where EXPO is the daily exposure to metals (mg/ (kg.day)), and RfD is the reference dose $(\mathrm{mg} /(\mathrm{kg}$.day $))$ suggested by the United States Environmental Protection Agency (USEPA) or World Health Organization (WHO). To evaluate exposure to two or more metals, HI [Eq. (2)] value was used to evaluate the total noncarcinogenic health risk [36]:

$$
\mathrm{HI}=\sum_{1}^{n} \mathrm{HQ}_{n} .
$$

If $\mathrm{HQ}$ or $\mathrm{HI}$ is less than 1, then no obvious noncarcinogenic risk exists. EXPO was determined using Eq. (3) [37]:

$$
\mathrm{EXPO}=\frac{C \times \mathrm{DI} \times \mathrm{EF} \times \mathrm{ED}}{\mathrm{BW} \times \mathrm{LT}},
$$

where $\mathrm{C}(\mathrm{mg} / \mathrm{kg})$ represents the concentration of PTEs in maize; DI (g/day) is the daily intake of maize; EF (day/year) is the exposure frequency determined from the questionnaire; ED (year) is the exposure duration; BW $(\mathrm{kg})$ is the body weight of residents determined from the questionnaire; and LT (year) is the lifetime of residents in days (presumed to be 70 years).

Carcinogenic risk $(R)$ caused by As was determined using Eq. (4) [37]:

$$
R=\mathrm{SF} \times \mathrm{EXPO} .
$$

The value of SF suggested by the USEPA is $1.5(\mathrm{mg} /$ $\mathrm{kg} /$ day $)^{-1}$ [37]. The negligible carcinogenic risk level suggested by the USEPA is $10^{-6}$, while the level set by the WHO is $10^{-5}$; the maximum acceptable level suggested by USEPA is $10^{-4}$ [38].

\section{Probabilistic assessment}

Probabilistic estimation was performed to assess uncertainty and variability in risk assessment. Monte Carlo technique was used because deterministic estimation only provides the mean value of population exposure and does not accurately estimate the exposure of the population. Monte Carlo technique was performed to calculate the distribution of exposure and health risk of the population.

Probabilistic distributions of the health risk were generated by inputting the variability in exposure factors. 
Based on the chemical analyses and questionnaires, the distributions of parameters (like concentration of metals, daily intake of maize, exposure frequency, and body weight, and so on) were determined. The best-fitting distribution for each variable was determined by fitting a number of parametric distributions (e.g., lognormal, gamma, and Weibull). Anderson-Darling (AD) test combined with other tests was used to determine the goodness-of-fit for each distribution. The process was realized using Oracle $\odot$ Crystal Ball software.

The probabilistic estimation of health risks, which was used Monte Carlo technique in Crystal Ball software, was based on the 10th, 50th, and 90th values. In the present study, Monte Carlo simulation was allowed to run for 10,000 iterations by drawing parameter values randomly from the distribution functions obtained before. The proportion of the population exceeding the acceptable health risk level was calculated.

\section{Sensitivity analysis}

Sensitivity analysis in Crystal Ball software was performed to confirm variables that pose the greatest effect on health risk. First, the rank correlation coefficients between the exposure factors and health risk were determined using probabilistic estimation. Subsequently, the contribution of each variable was calculated by squaring the variance. Finally, the results were normalized to $100 \%$, and the sequence of contributing variables was generated.

\section{Statistical methods}

Mean, standard deviation (SD), minimum, maximum, and variable coefficient (C.V) were calculated in Microsoft Excel 2010 (Microsoft Ins., USA). ANOVA and correlation analysis were performed in SPSS 17.0 (IBM Ins., USA). The determination of the best-fitting distribution, Monte Carlo simulation, and sensitivity analysis were all carried out in Crystal Ball software (Oracle` Ins., USA). ArcGIS Desktop 10 (ESRI Ins., USA, Authorization number: EFL564098460) was used to map the sampling sites.

\section{Results}

PTEs levels in maize, associated soil, and irrigation water Some important physicochemical properties of soil and water were shown as follows: The soil $\mathrm{pH}$ was $8.47 \pm 0.55$ and the $\mathrm{OM}$ was $17.92 \pm 8.52 \mathrm{~g} / \mathrm{kg}$. The water $\mathrm{pH}$ was $8.13 \pm 0.87$ and the EC was $830.27 \pm 50.28 \mu \mathrm{s} / \mathrm{cm}$. The PTE concentrations in maize grains, associated soil, and irrigation water are presented in Table 1. The average concentrations of $\mathrm{Cd}, \mathrm{Pb}, \mathrm{Cr}, \mathrm{Zn}, \mathrm{Cu}$, and $\mathrm{As}$ in maize grains were $0.037,0.41,2.36,17.02,1.04$, and $0.17 \mathrm{mg} / \mathrm{kg}$, respectively. The maximum allowable concentrations of the six metals in food are $0.1(\mathrm{Cd}), 0.2(\mathrm{~Pb}), 1.0(\mathrm{Cr}), 50$ $(\mathrm{Zn}), 10(\mathrm{Cu})$ and $0.5(\mathrm{As}) \mathrm{mg} / \mathrm{kg}[39,40]$. Thus, the average concentrations of $\mathrm{Pb}$ and $\mathrm{Cr}$ exceeded the maximum allowable concentrations in food. However, the concentrations of the four remaining metals exceeded the standards in some samples. The measured metal level exceeded the limit, and the metal with the highest percentage was $\mathrm{Cr}$ (69\%) followed by $\mathrm{Pb}(47 \%)$, As (18\%), and Cd (2\%). The average PTE concentrations in the soil samples were 0.14, $18.16,37.25,138.20,19.61$, and $14.18 \mathrm{mg} / \mathrm{kg}$ for $\mathrm{Cd}, \mathrm{Pb}$, $\mathrm{Cr}, \mathrm{Zn}, \mathrm{Cu}$, and As, respectively, with large variation among the samples. The average concentrations of $\mathrm{Zn}$ and As exceeded the standards (GB15618-2018) for soils in China [41] with over-limit ratio of 18 and 4\%, respectively. The background concentrations in Ningxia were $0.11(\mathrm{Cd}), 20.6(\mathrm{~Pb}), 60.0(\mathrm{Cr}), 58.8(\mathrm{Zn}), 22.1(\mathrm{Cu})$, and 11.90 (As) $\mathrm{mg} / \mathrm{kg}$ [42]. Thus, the $\mathrm{Zn}$ level in the soil measured in this study was remarkably higher than the background value, the $\mathrm{Cr}$ level was lower, and the levels of the other metals were similar to the background values. Some sampling sites in this study were close to the industrial parks, which might explain the high metal concentrations found at these sites. However, source identification should be conducted to better understand the results. In the irrigation water samples, the mean concentrations of the six PTEs were $0.11(\mathrm{Cd}), 1.12(\mathrm{~Pb}), 41.03$ (Cr), 0.91 (Zn), 1.60 $(\mathrm{Cu})$, and $3.60(\mathrm{As}) \mu \mathrm{g} / \mathrm{L}$, which were below the limits acceptable in China (GB 5084-2005) [33]. The correlation analysis results showed the soil $\mathrm{pH}$ was significantly positively correlated with $\mathrm{Zn}$ concentration in maize $(P<$ $0.05)$, and $\mathrm{OM}$ in soil was significantly negatively correlated with $\mathrm{Pb}$ concentration.

Bioaccumulation factor (BF) is an index used to evaluate the transfer potential of a metal from soil to plant [43]. In the present study, BF was calculated by the concentration of metal in maize relative to that in the corresponding soil. A BF value higher than 1 indicates a high level of metal accumulation in the plant, and a BF value lower than 1 denotes a low level of metal accumulation in the plant [44]. The BF values were far less than 1 for all six PTEs, indicating the low levels of metal accumulation in maize grains. The BF values of the six metals followed the following sequence: $\mathrm{Cd}>\mathrm{Zn} \approx \mathrm{As}>\mathrm{Cr}>\mathrm{Cu}>\mathrm{Pb}$. The accumulation ability of $\mathrm{Cd}$ was the highest, while that of $\mathrm{Pb}$ was the lowest in maize. The results of correlation analysis (Table 2S) showed that the correlation between the BFs of $\mathrm{Pb}, \mathrm{Zn}$, and $\mathrm{Cr}$ had significant negative $(P<0.01)$ correlations with the corresponding PTEs in soil, while the BF of $\mathrm{Cd}$ had significant positive correlations $(P<0.01)$ with $\mathrm{Cd}$ in soil. Moreover, the relationships of the BFs of all PTEs and corresponding PTEs in maize were significantly positively correlated $(p<0.01)$.

\section{Body weight, daily consumption of maize, and exposure frequency of maize}

The results for resident BW, DI, and EF are summarized in Table 2. Of the 103 local inhabitants who participated 
Table 1 The concentrations of PET in maize, the associated soil and the irrigation water

\begin{tabular}{|c|c|c|c|c|c|c|c|}
\hline & & $\mathrm{Cd}$ & $\mathrm{Pb}$ & $\mathrm{Cr}$ & $\mathrm{Zn}$ & $\mathrm{Cu}$ & As \\
\hline \multirow{7}{*}{$\begin{array}{l}\text { Miaze }(\mathrm{mg} / \mathrm{kg}) \\
n=45\end{array}$} & mean & 0.037 & 0.41 & 2.36 & 17.02 & 1.04 & 0.17 \\
\hline & SD & 0.024 & 0.42 & 4.21 & 10.45 & 0.73 & 0.24 \\
\hline & $\operatorname{mix}$ & 0.00025 & ND & ND & 0.84 & 0.0080 & ND \\
\hline & $\max$ & 0.14 & 2.66 & 23.08 & 39.4 & 2.57 & 0.73 \\
\hline & C.V & $63 \%$ & $137 \%$ & $184 \%$ & $61 \%$ & $70 \%$ & $136 \%$ \\
\hline & Safe limits ${ }^{a}$ & 0.1 & 0.2 & 1.0 & 50 & 10 & 0.5 \\
\hline & Over-limit ratio & $2 \%$ & $47 \%$ & $69 \%$ & $0 \%$ & $0 \%$ & $18 \%$ \\
\hline \multirow{8}{*}{$\begin{array}{l}\text { Soil }(\mathrm{mg} / \mathrm{kg}) \\
\mathrm{n}=45\end{array}$} & mean & 0.14 & 18.16 & 37.25 & 138.20 & 19.61 & 14.18 \\
\hline & SD & $119 \%$ & $38.9 \%$ & $27.6 \%$ & $104 \%$ & $96.5 \%$ & $21 \%$ \\
\hline & $\operatorname{mix}$ & ND & 0.64 & 19.7 & 39.21 & $2.37-$ & 9.08 \\
\hline & $\max$ & 0.45 & 35.08 & 65.74 & 542.27 & 77.82 & 21.24 \\
\hline & C.V & $119 \%$ & $38.9 \%$ & $27.6 \%$ & $104 \%$ & $96.5 \%$ & $21 \%$ \\
\hline & Safe limits ${ }^{\mathrm{b}}(\mathrm{pH}>7.5)$ & 0.8 & 240 & 350 & 300 & 200 & 20 \\
\hline & Over-limit ratio & $0 \%$ & $0 \%$ & $0 \%$ & $18 \%$ & $0 \%$ & $4 \%$ \\
\hline & $\mathrm{BF}=\mathrm{C}_{\text {maize }} / \mathrm{C}_{\text {soil }}$ & 0.26 & 0.023 & 0.063 & 0.12 & 0.053 & 0.12 \\
\hline \multirow{7}{*}{$\begin{array}{l}\text { Irrigation water }(\mu \mathrm{g} / \mathrm{L}) \\
n=5\end{array}$} & mean & 0.11 & 1.12 & 41.03 & 0.91 & 1.60 & 3.60 \\
\hline & SD & 0.14 & 2.01 & 28.90 & 0.72 & 0.82 & 1.27 \\
\hline & $\operatorname{mix}$ & ND & 0.045 & ND & 0.095 & 0.74 & 2.40 \\
\hline & $\max$ & 0.40 & 5.90 & 71.00 & 1.90 & 2.70 & 6.10 \\
\hline & C.V & $126 \%$ & $177 \%$ & $70 \%$ & $79 \%$ & $52 \%$ & $36 \%$ \\
\hline & Safe limits ${ }^{c}$ & 10 & 200 & 100 & 2000 & 500 & 50 \\
\hline & Over-limit ratio & $0 \%$ & $0 \%$ & $0 \%$ & $0 \%$ & $0 \%$ & $0 \%$ \\
\hline
\end{tabular}

ND means not detected

a means allowable levels of heavy metals for corns in China by GB 2762-2017and NY 861-2004 standards;

${ }^{b}$ means allowable levels of heavy metals for soil in China by GB15618-2018 standard;

' means allowable levels of heavy metals for irrigated water in China by GB 5084-2005 standard

in this study, $49 \%$ were male, and $51 \%$ were female. In older to eliminate differences in size of the age population and considering the data of the present study, interval of 20 years was selected to divide the age group. Therefore, the participants were classified into four age groups: below 20 years, $20-40$ years, $40-60$ years, and more than 60 years old (occupying 25, 34, 26, and 15\% of participants, respectively). The average BWs of all participants, male participants, and female participants were $54.60,58.45$, and $50.67 \mathrm{~kg}$, respectively. Based on the reported statistics, the average BW values for adults in China are $62.7 \mathrm{~kg}$ for males and $54.4 \mathrm{~kg}$ for females [45]. The average BWs was slightly lower than the reported values possibly because children were considered in the current study.

In this study, the maize DI was slightly less for males $(160.20 \mathrm{~g} /$ day $)$ than for females $(162.08 \mathrm{~g} /$ day $)$. Among the different age groups, DI was the highest $(186.37 \mathrm{~g} /$ day) in the 20-40 age group followed by the 40-60 $(181.48 \mathrm{~g} /$ day $)$ and $>60(136.36 \mathrm{~g} /$ day $)$ groups. The $<20$ group had the lowest DI of $118.46 \mathrm{~g} /$ day. The maize EF was also lower for males (14.34 day/year) than for females (16.67 day/year). In contrast to DI, EF was the highest in the $<20$ age group (17.81 day/year) followed by the 40-60 ( 17.11 day/year) and 20-40 (14.06 day/ year) age groups. The $>60$ group had the lowest EF of 10.36 day/year. BW, DI, and EF affected health risk, and their degrees of influence were evaluated by sensitivity analysis.

\section{Human health risk assessment Deterministic assessment}

The oral RfD values were established as 1, 1500, 300, 40, and $0.3 \mu \mathrm{g} / \mathrm{kg} / \mathrm{day}$ for $\mathrm{Cd}, \mathrm{Cr}, \mathrm{Zn}, \mathrm{Cu}$, and As, respectively [17]. The RfD value for $\mathrm{Pb}$ was $3.57 \mu \mathrm{g} / \mathrm{kg} /$ day according to the provisional tolerable weekly intake level $(25 \mu \mathrm{g} / \mathrm{kg} /$ week $)$ [46] set by the WHO.

The results of the deterministic estimation of health risk are shown in Table 3. The HQ values indicate that no individual metal posed a significant non-carcinogenic risk $(\mathrm{HQ}<1)$. For all inhabitants, the non-carcinogenic health risk posed by the different metals decreased in the following order: $\mathrm{As}>\mathrm{Pb}>\mathrm{Zn}>\mathrm{Cd}>\mathrm{Cu}>\mathrm{Cr}$. The combined non-carcinogenic health risk $\mathrm{HI}$ values were 
Table 2 Exposure factors of the inhabitants by gender and age groups (mean \pm SD)

\begin{tabular}{lllll}
\hline & $\mathbf{n}$ (person) & Body weight $\mathbf{( k g )}$ & Daily intake of maize (g/day) & Exposure frequency (day/year) \\
\hline All & 103 & $54.60 \pm 18.56$ & $161.13 \pm 97.16$ & $15.50 \pm 8.45$ \\
Male & 50 & $58.45 \pm 18.28$ & $160.20 \pm 96.27$ & $14.34 \pm 7.47$ \\
Female & 53 & $50.67 \pm 18.19$ & $162.08 \pm 99.06$ & $16.67 \pm 9.28$ \\
$<20$ & 26 & $30.92 \pm 15.37$ & $118.46 \pm 83.03$ & $17.81 \pm 8.75$ \\
$20 \sim 40$ & 35 & $62.55 \pm 10.73$ & $186.37 \pm 95.42$ & $14.06 \pm 6.13$ \\
$40 \sim 60$ & 27 & $65.78 \pm 7.68$ & $181.48 \pm 105.75$ & $17.11 \pm 10.11$ \\
\hline
\end{tabular}

also less than 1 , indicating that maize consumption was not associated to have an obvious non-carcinogenic health risk due to PTEs. The HI values for females were greater than those for males, implying that females experienced more potential non-carcinogenic health risks from PTEs than males. This finding can be attributed to the higher DI and EF but lower BW of females compared with males. Among the different age groups, the HI decreased in the following order: below 20 years > $40-60$ years $>20-40$ years $>$ more than 60 years. Similarly, one study indicated that children are at a greater health risk than adults from the consumption of an individual metal in maize [47].

In terms of carcinogenic risk caused by As, the average $R$ value for all participants was $3.261 \times 10^{-5}$, which was lower than the maximum acceptable carcinogenic level set by the USEPA $\left(10^{-4}\right)$ but higher than the negligible risk levels set by the USEPA $\left(10^{-6}\right)$ and WHO $\left(10^{-5}\right)$. Among the age groups, the $R$ values decreased in the same order as the HI values: below 20 years $>40-60$ years $>20-40$ years $>$ more than 60 years. In addition, the ANOVA results showed no significant difference in health risk between males and females $(P=0.137, P>0.05)$. For different age groups, the health risk of age group of the below 20 years group was significantly higher than that of the more than 60 years group $(P=0.024, P<0.05)$.

\section{Probabilistic assessment}

The best-fitting distributions of exposure factors were determined using Crystal Ball software. The concentrations of the metals in maize were fitted to lognormal distributions, except for the $\mathrm{Cu}$ concentration, which was fitted to a beta distribution. All DI, EF, and BW values were fitted to lognormal distributions, except for the BWs of males (Poisson) and females (negative binomial).

The results of the probabilistic estimation of health risk are summarized in Table 4. For non- carcinogenic risk, all HI values were fitted to lognormal distributions. The 10th, 50th, and 90th percentile HI values were 0.02, 0.06, and 0.25 for all inhabitants; $0.01,0.05$, and 0.18 for males; and $0.02,0.07$, and 0.29 for females, respectively. Approximately 0.62\% (all inhabitants; Fig. 2a), 0.22\% (male inhabitants; Fig. 2b), and $1.17 \%$ (female inhabitants; Fig. 2c) had HI values greater than 1, indicating slight non-carcinogenic risk. Among the age groups, the 90th percentile $\mathrm{HI}$ value was the highest $(0.40)$ for inhabitants aged below 20 years and the lowest for those aged more than 60 years (0.11). Approximately $2.07 \%$ (under 20 years old), $0.28 \%$ (20-40), $0.53 \%$ (40-60), and $0.04 \%$ (over 60 years old) of inhabitants had HI values greater than 1 (Fig. 3), indicating very low non-carcinogenic risk in all age groups. Basing on the HI values determined via probabilistic estimation, we can conclude that the non-carcinogenic health risks resulting from the studied metals are not significant.

To evaluate carcinogenic risk, all $R$ values were also fitted to lognormal distributions. The 10th, 50th, and 90th values of $R$ for all inhabitants were $0.29 \times 10^{-5}$, $1.61 \times 10^{-5}$, and $8.62 \times 10^{-5}$, respectively. The value of $R$ exceeded the maximum acceptable level of $1 \times 10^{-4}$ (USEPA) in $8.23 \%$ of inhabitants (Fig. 2d), while $R$ was

Table 3 Non-carcinogenic risk $H Q$, $H$ l value of heavy metals and carcinogenic risk $\mathrm{R}$ value of As due to consumption of maize by deterministic estimation method

\begin{tabular}{llllllllll}
\hline & \multicolumn{2}{l}{ Non-carcinogenic risk (HQ) } & & & & \multicolumn{2}{c}{ Carcinogenic risk (R) } \\
\cline { 2 - 6 } & $\mathbf{C d}$ & $\mathbf{P b}$ & $\mathbf{C r}$ & $\mathbf{Z n}$ & $\mathbf{C u}$ & $\mathbf{A s}$ & & HI & As \\
\hline All & 0.0048 & 0.0109 & 0.0002 & 0.0071 & 0.0033 & 0.0725 & 0.0986 & $3.261 \mathrm{E}-05$ \\
Male & 0.0041 & 0.0093 & 0.0002 & 0.0061 & 0.0028 & 0.0623 & 0.0848 & $2.804 \mathrm{E}-05$ \\
Female & 0.0055 & 0.0127 & 0.0002 & 0.0083 & 0.0038 & 0.0845 & 0.1150 & $3.802 \mathrm{E}-05$ \\
$<20$ & 0.0071 & 0.0162 & 0.0003 & 0.0106 & 0.0049 & 0.1081 & 0.1472 & $4.864 \mathrm{E}-05$ \\
$20 \sim 40$ & 0.0044 & 0.0100 & 0.0002 & 0.0065 & 0.0030 & 0.0664 & 0.0904 & $2.987 \mathrm{E}-05$ \\
$40 \sim 60$ & 0.0049 & 0.0112 & 0.0002 & 0.0073 & 0.0034 & 0.0748 & 0.1018 & $3.366 \mathrm{E}-05$ \\
$>60$ & 0.0025 & 0.0057 & 0.0001 & 0.0037 & 0.0017 & 0.0378 & 0.0514 & $1.700 \mathrm{E}-05$ \\
\hline
\end{tabular}


Table 4 The statistics of probabilistic estimation of $H$ and $\mathrm{R}$ values

\begin{tabular}{|c|c|c|c|c|c|c|c|c|c|c|}
\hline & \multicolumn{5}{|c|}{ Non- carcinogenic risk (HI) } & \multicolumn{5}{|c|}{ Carcinogenic risk $(\mathrm{R})\left(\times 10^{-5}\right)$} \\
\hline & Distribution & Parameters & $10 \%$ & $50 \%$ & $90 \%$ & Distribution & Parameters & $10 \%$ & $50 \%$ & $90 \%$ \\
\hline All & Lognormal & Location:0.00, Mean:0.11, SD:0.18 & 0.02 & 0.06 & 0.25 & Lognormal & $\begin{array}{l}\text { Location:0.00, Mean: } 3.8 \text {, } \\
\text { SD: } 8.3\end{array}$ & 0.29 & 1.61 & 8.62 \\
\hline Male & Lognormal & Location:0.01, Mean:0.08, SD:0.11 & 0.01 & 0.05 & 0.18 & Lognormal & $\begin{array}{l}\text { Location:0.00, Mean:4.4, } \\
\text { SD: } 9.5\end{array}$ & 0.26 & 1.28 & 6.35 \\
\hline Female & Lognormal & Location:0.00, Mean:0.13, SD:0.20 & 0.02 & 0.07 & 0.29 & Lognormal & $\begin{array}{l}\text { Location:0.00, Mean: } 3.3 \text {, } \\
\text { SD: } 2.0\end{array}$ & 0.34 & 1.85 & 10.03 \\
\hline$<20$ & Lognormal & Location:0.00, Mean:0.18, SD:0.29 & 0.02 & 0.09 & 0.40 & Lognormal & $\begin{array}{l}\text { Location:0.00, Mean: } 2.5 \text {, } \\
\text { SD: } 3.7\end{array}$ & 0.40 & 2.31 & 13.40 \\
\hline $20 \sim 40$ & Lognormal & Location:0.00, Mean:0.09, SD:0.12 & 0.02 & 0.06 & 0.20 & Lognormal & $\begin{array}{l}\text { Location:0.00, Mean: } 3.1 \text {, } \\
\text { SD: } 5.7\end{array}$ & 0.32 & 1.51 & 7.11 \\
\hline $40 \sim 60$ & Lognormal & Location:0.00, Mean:0.10, SD:0.14 & 0.02 & 0.06 & 0.22 & Lognormal & $\begin{array}{l}\text { Location:0.00, Mean: 3.4, } \\
\text { SD: } 6.9\end{array}$ & 0.30 & 1.54 & 7.70 \\
\hline$>60$ & Lognormal & Location:0.00, Mean:0.05, SD:0.06 & 0.01 & 0.03 & 0.11 & Lognormal & $\begin{array}{l}\text { Location:0.00, Mean: } 1.8 \\
\text { SD: } 3.2\end{array}$ & 0.19 & 0.88 & 4.07 \\
\hline
\end{tabular}

greater than the negligible level of $1 \times 10^{-5}$ (WHO) for approximately $64.26 \%$ of inhabitants (Fig. 1Sa). The 10th, 50th, and 90th values of $R$ were $0.26 \times 10^{-5}, 1.28 \times$ $10^{-5}$, and $6.35 \times 10^{-5}$ for males and $0.34 \times 10^{-5}, 1.85 \times$ $10^{-5}$, and $10.03 \times 10^{-5}$ for females, respectively. Approximately $5.12 \%$ of male inhabitants (Fig. 2e) and $10.46 \%$ of female inhabitants (Fig. 2f) had $R$ values greater than $1 \times 10^{-4}$, while $58.28 \%$ of male inhabitants and $68.30 \%$ of female inhabitants had $R$ values greater than $1 \times 10^{-5}$ (Fig. $1 \mathrm{Sb}$ and Fig. 1Sc); thus, the carcinogenic risk was greater for females than for males. The respective 10th, 50th, and 90th values of $R$ were $0.40 \times$ $10^{-5}, 2.31 \times 10^{-5}$, and $13.40 \times 10^{-5}$ for inhabitants aged below 20 years; $0.32 \times 10^{-5}, 1.51 \times 10^{-5}$, and $7.11 \times 10^{-5}$ for inhabitants aged 20-40 years; $0.30 \times 10^{-5}, 1.54 \times$ $10^{-5}$, and $7.70 \times 10^{-5}$ for inhabitants aged $40-60$ years; and $0.19 \times 10^{-5}, \quad 0.88 \times 10^{-5}$, and $4.07 \times 10^{-5}$ for inhabitants aged more than 60 years old. Approximately $14.81 \%$ (under 20 years old), 7.18\% (20-40), 5.83\% (4060 ), and $2.08 \%$ (over 60 years old) of inhabitants had $R$ values greater than $1 \times 10^{-4}$ (Fig. 4), while $73.24 \%$ (under 20 years old), $63.26 \%$ (20-40), 63.47\% (40-60), and $45.74 \%$ (over 60 years old) of inhabitants had $R$ values greater than $1 \times 10^{-5}$ (Fig. 2S). Thus, the carcinogenic risk differed among the age groups.

\section{Sensitivity results}

The sensitivity analyses showed that the contributions of As concentration, maize $\mathrm{DI}$, maize $\mathrm{EF}$, and $\mathrm{Pb}$ concentration to non-carcinogenic risk were 35.8, 29.4, 20.7, and $1.8 \%$, respectively. The contributions of As concentration, maize DI, and maize EF to carcinogenic risk were $61.0,18.5$, and $13.1 \%$, respectively. These results

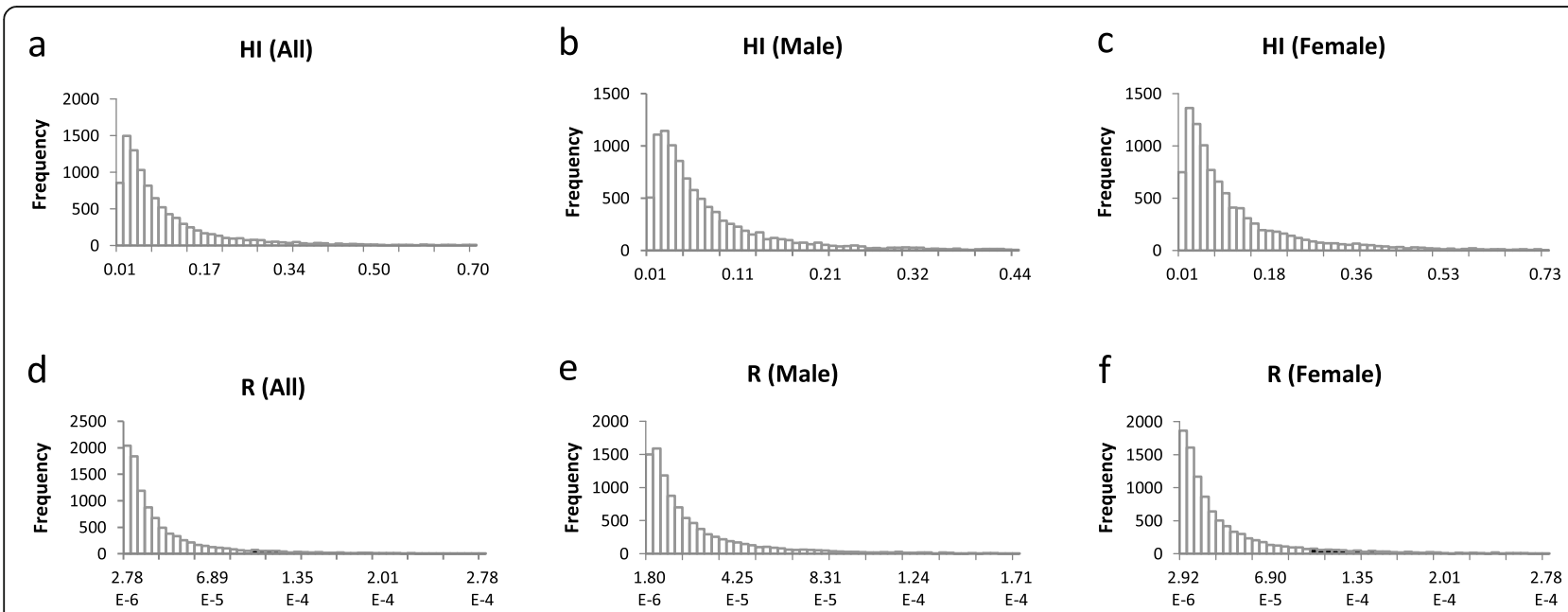

Fig. 2 Probability exceeding 1 of $\mathrm{HI}$ (a: all inhabitants, b: male, c: female) and $10^{-4}$ of R (d: all inhabitants, e: male, f: female). The black area represents the exceeding probabilities, which were $0.62,0.22,1.17,8.23,5.12$ and $10.46 \%$ for $\mathbf{a}, \mathbf{b}, \mathbf{c}, \mathbf{d}$, e and $\mathbf{f}$, respectively 


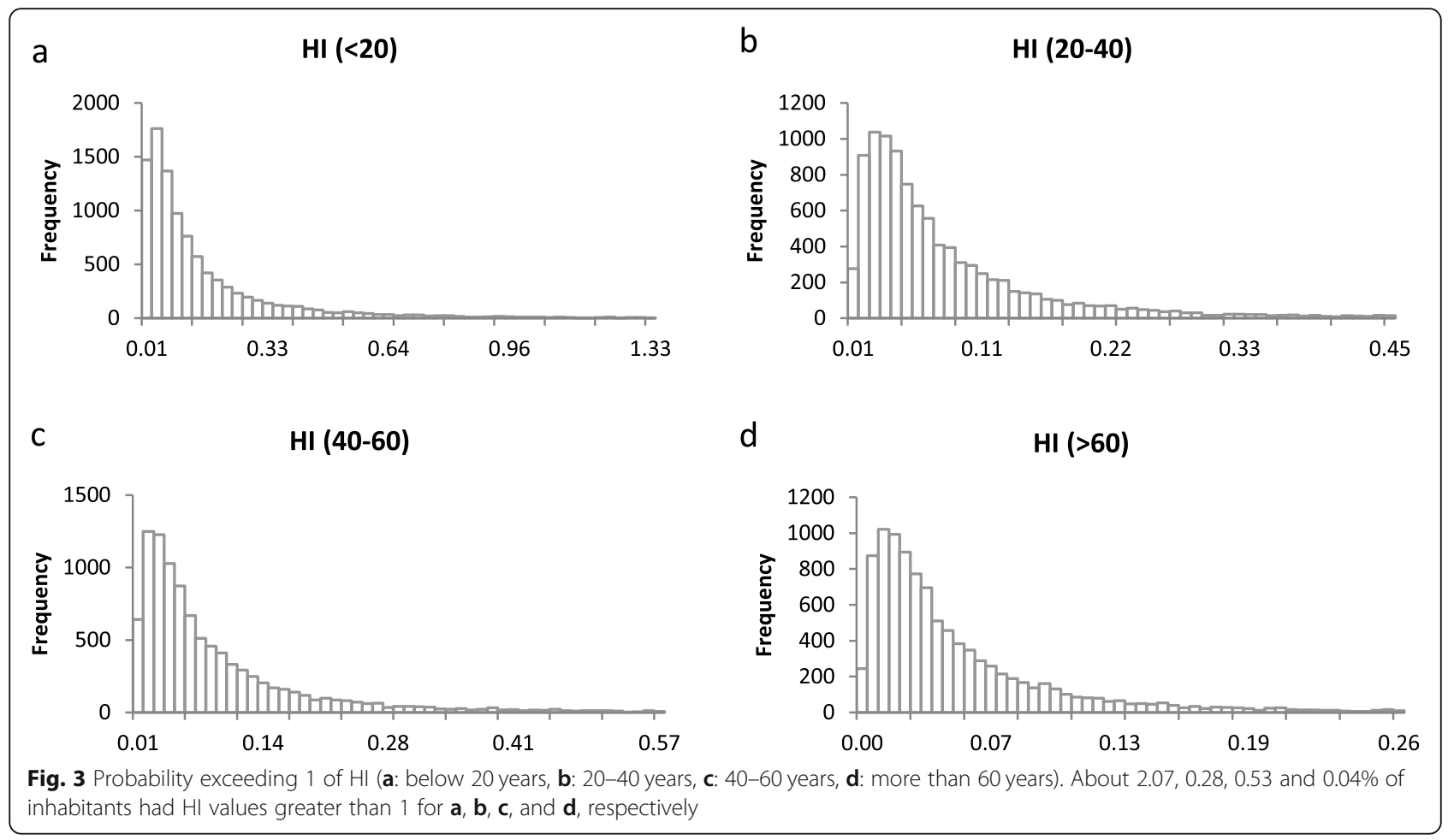

imply that controlling the concentration of As would effectively reduce the health risk for local inhabitants.

\section{Discussion}

\section{Levels of PTEs and BF in maize}

The PTE concentration in samples of maize irrigated by waste water were significantly higher $(P<0.05)$ than that irrigated by unpolluted water [48]. The PTE levels of Cd, $\mathrm{Pb}, \mathrm{Cr}, \mathrm{Zn}, \mathrm{Cu}$, and $\mathrm{As}$ in maize growing near a petrochemical industry complex were 0.0442, 0.0595, 0.2996, $20.42,4.49$, and $0.0428 \mathrm{mg} / \mathrm{kg}$, respectively [49], and the levels of $\mathrm{Pb}, \mathrm{Cr}, \mathrm{Cu}$, and $\mathrm{As}$ were lower than the present results; hence, maize in the current study was more contaminated. Maize in another industrial area was found to

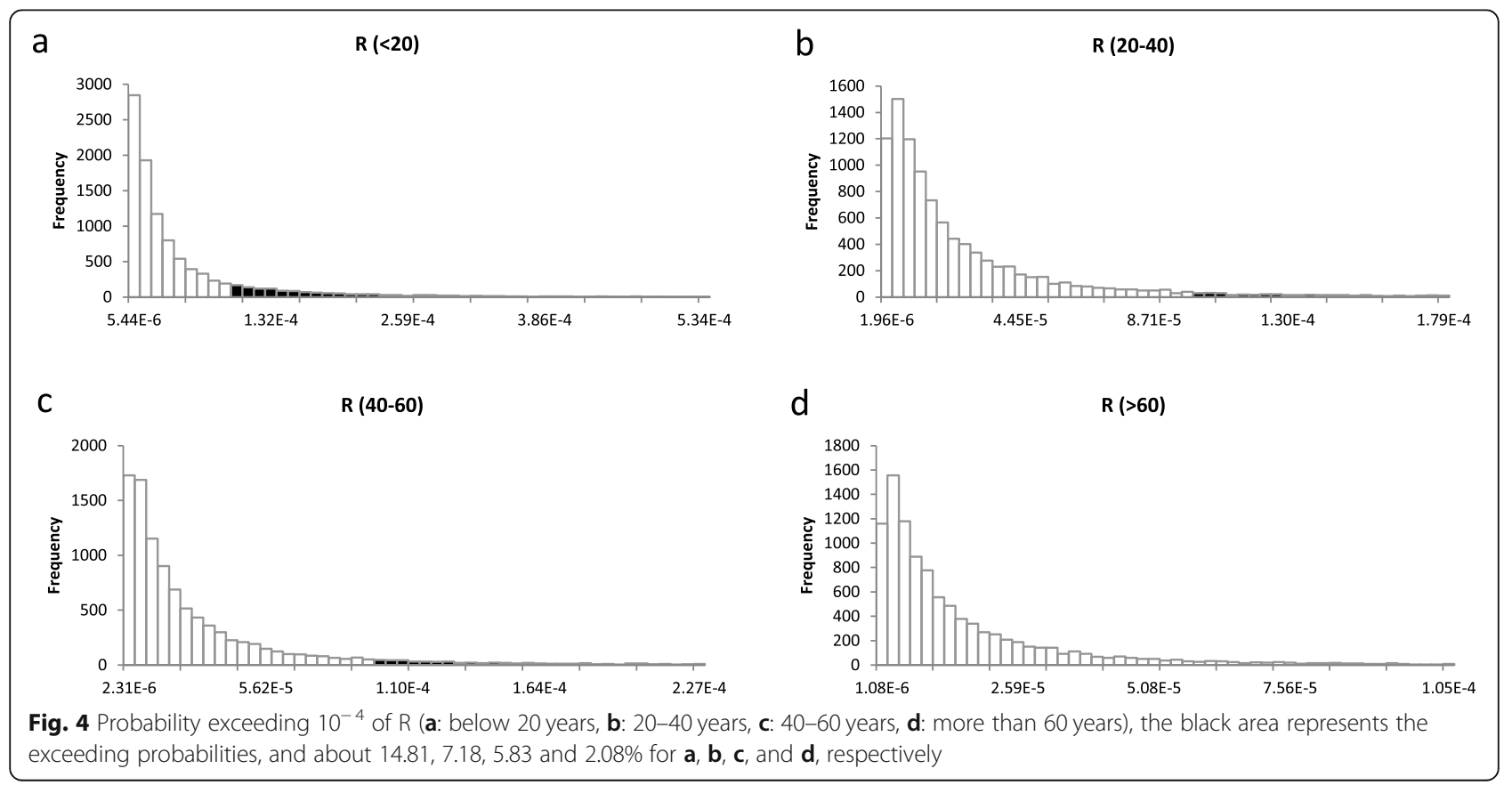


have $\mathrm{Pb}, \mathrm{Cd}, \mathrm{Zn}$, and $\mathrm{Cu}$ levels of were $0.129,0.021,3.4$, and $2.6 \mathrm{mg} / \mathrm{kg}$, respectively [50], which were below the standard values and our study values. Although their study area was an industrial area, the maize samples were collected from a market and may not have been grown near an industrial zone.

Previous study found that maize grains have lower BF values compared with other parts [51], indicating the low accumulation ability of PTEs in maize grains. Researchers also found that $\mathrm{Cd}$ is the easiest transferred metal, and $\mathrm{Pb}$ is the hardest transferred metal in maize [51, 52]. Wang et al. [53] collected data from many previous studies and fitted the accumulation equations of PTEs in maize grains. A parameter in the accumulation equation that reflected accumulation ability for $\mathrm{Cd}$ was the highest, while that for $\mathrm{Pb}$ was the lowest. Their results could prove findings of the present study. The BFs of PTEs in some other plants were consistent with maize. Zhuang et al. [54] found that the $\mathrm{BF}$ of $\mathrm{Pb}$ in soybeans was less than that of other PTEs. Wang et al. [53] reported $\mathrm{Cd}$ in wheat grains was more mobile than other PTEs and the BF of PTEs was also significantly correlated with corresponding PTEs in soil. Moreover, The BFs were related to plant species, heavy metal type, and the surrounding environment. In soil-plant system, PTE accumulations in plant are mainly dependent on metal activity and are greatly influenced by physicochemical properties of soil [55]. For example, high $\mathrm{pH}$ makes soil electronegative, thereby increasing the mobility of heavy metals and facilitating the metal adsorption by plants [56]. Organic matter in soil easily combines with metal ions and form organic complexes, which can reduce the availability, mobility, and accumulation of metals [57]. The present results were consistent with the explanation.

The PTE contents in irrigation water were very similar to a previous report, which indicated PTEs concentrations in their filtered water samples of Cd (ND-0.11 $\mu \mathrm{g} /$ $\mathrm{L}), \mathrm{Cr}(74.80-94.70 \mu \mathrm{g} / \mathrm{L}), \mathrm{Cu}(0.68-2.79 \mu \mathrm{g} / \mathrm{L}), \mathrm{Pb}(\mathrm{ND}-$ $0.82 \mu \mathrm{g} / \mathrm{L})$, and $\mathrm{Zn}(0.19-1.82 \mu \mathrm{g} / \mathrm{L})$ [21]. However, the above samples along with the water samples in the present study were filtered and did not include suspended particles or sediment. According to another study, the PTE concentrations in suspended particulate matter of the Yellow River were $0.428 \mathrm{mg} / \mathrm{kg}$ for $\mathrm{Cd}$, $74.9 \mathrm{mg} / \mathrm{kg}$ for $\mathrm{Cr}, 40.1 \mathrm{mg} / \mathrm{kg}$ for $\mathrm{Cu}, 32.6 \mathrm{mg} / \mathrm{kg}$ for $\mathrm{Pb}$, and $13.6 \mathrm{mg} / \mathrm{kg}$ for As [58], which were below the standards set for soils but higher than the background values in local soil. Moreover, the PTEs concentrations in suspended particles and sediment from the Yellow River [21] were as follows: $\mathrm{Cd}(0.23-1.09 \mathrm{mg} / \mathrm{kg}), \mathrm{Cr}(64.50-$ $84.90 \mathrm{mg} / \mathrm{kg}), \mathrm{Cu}(25.40-42.20 \mathrm{mg} / \mathrm{kg}), \mathrm{Pb}(20.80-31.70$ $\mathrm{mg} / \mathrm{kg})$, and $\mathrm{Zn}(72.50-107.00 \mathrm{mg} / \mathrm{kg})$ for suspended particles and Cd (0.23-1.09 mg/kg), Cr (64.50-84.90 mg/ $\mathrm{kg}), \mathrm{Cu}(25.40-42.20 \mathrm{mg} / \mathrm{kg}), \mathrm{Pb}(20.80-31.70 \mathrm{mg} / \mathrm{kg})$, and $\mathrm{Zn}(72.50-107.00 \mathrm{mg} / \mathrm{kg})$ for sediments. These results imply that PTEs in the Yellow River primarily accumulate in suspended particles and sediment, which should receive more attention.

\section{Health risk assessment}

Non-carcinogenic risk caused by PTEs through maize consumption was not obvious in other reports, similar to the present study. For the contribution of different PTEs to non-carcinogenic risk through maize consumption, the order of this study was $\mathrm{As}>\mathrm{Pb}>\mathrm{Zn}>\mathrm{Cd}>$ $\mathrm{Cu}>\mathrm{Cr}$. Hu et al. [52] also found As was the major contributor to health risk. El-Hassanin et al. [47] found that $\mathrm{Pb}$ showed higher level of health risk index than $\mathrm{Cd}$. However, $\mathrm{Yu}$ et al. [59] found $\mathrm{Zn}$ and $\mathrm{Cu}$ were the most important contributors to health risk (>80\%). Carcinogenic risk caused by As through maize consumption was seldom studied. Most reports have focused on carcinogenic risk resulting from rice consumption [60-62], Jiang et al. [63] found that among different food sources, rice has the greatest contribution to total As daily intake.

In the present study, the estimates of health risk from PTE exposure are only for maize consumption and do not account for any other sources. In reality, health risk is affected by various sources of PTEs such as different foodstuffs (e.g., rice, wheat, and vegetables) and drinking water. Cai et al. [64] found rice consumption was the major source of PTEs exposure which accounting for more than $70 \%$ of the total HQs. The intake of vegetables was a second important source with approximately $10 \%$ of the total HQs. Cao et al. [26] also observed rice consumption was the major contributor to $\mathrm{HI}$, and vegetable intake was the next greatest contributor.

Other pathways of PTE exposure including dust inhalation and dermal contact also contribute to health risks. $\mathrm{Hu}$ et al. [52] calculated health risk under three pathways (ingestion, dermal contact, and inhalation) of exposure to heavy metals in soil and found that ingestion was the main pathways associated with health risk. Sawut et al. [65] found the ingestion and/or dermal contact of soil carcinogenic risk lead by As was higher than the acceptable risk level. Therefore, exposure from other sources should be considered to estimate the total risk in future works.

\section{The uncertainties of risk assessment}

Health risk assessment of PTEs through food consumption in previous reports was mainly assessed by deterministic estimation; however, deterministic assessment may overestimate or underestimate risks because of the uncertainty of metal concentration and the variability of exposure parameters. Probabilistic estimation is 
introduced to provide additional useful information. The proportion of residents exceeding RfDs could be obtained, and correlations between different variables and risk results could be provided. Cao et al. [26] evaluated potential health risks using probabilistic estimation and found that $0.00,4.18,0.36,0.03,0.00$ and $0.00 \%$ of inhabitants exceeded the corresponding $\mathrm{RfD}$ for $\mathrm{Cr}, \mathrm{Cu}, \mathrm{Zn}$, $\mathrm{Cd}, \mathrm{Hg}$ and $\mathrm{Pb}$, respectively. Hang et al. [64] found that $3.9,1.9$, and $0.6 \%$ of inhabitants exceeded the corresponding $\mathrm{RfD}$ for $\mathrm{Cu}, \mathrm{Pb}$, and $\mathrm{Cd}$, respectively. Jiang et al. [60] found the proportion of inhabitants exceeding the RfD of As was $27.85 \%$ and daily intake of rice, metal concentration in rice and body weight were most relevant variables to health risk results. These previous studies only focused on element exposure and paid less attention to different populations. In the present study, we calculated the proportion exceeding the threshold value for $\mathrm{HI}$ and $\mathrm{R}$ in different gender and age groups. The corresponding results would provide suggestion to different populations to consume maize.

\section{Conclusion}

Although the average PTE concentrations in soil and irrigation water did not exceed the national standards, the average contents of two metals $(\mathrm{Pb}$ and $\mathrm{Cr}$ ) in maize exceeded the standards for food. The BF values of the six metals in maize were all at low levels and the accumulation ability followed the order of $\mathrm{Cd}>\mathrm{Zn}=\mathrm{As}>\mathrm{Cr}>\mathrm{Cu}>$ $\mathrm{Pb}$. The non-carcinogenic health risks to inhabitants was not obvious $(\mathrm{HI}<1)$, while the carcinogenic risk from As exposure was lower than the maximum acceptable level and higher than the negligible level. Females are at greater risk than males, but the difference was not significant. Health risks were the highest in the age group of below 20 years. Among different exposure factors, arsenic level and daily intake of maize were the most sensitive factors that affect the health risk results.

\section{Supplementary Information}

The online version contains supplementary material available at https://doi. org/10.1186/s12889-020-09845-5.

Additional file 1: Table S1. The results of quality control in maize, the associated soil and the irrigation water. Table S2. Correlations between BF and levels of PTEs in soil and maize. Fig. S1. Probability exceeding $10^{-5}$ of $\mathrm{R}$ (a: all inhabitant, b: male c: female), the black area represents the exceeding probabilities, and about $64.26,58.28$ and $68.30 \%$ for $a, b, c$, and $d$, respectively. Fig. S2. Probability exceeding $10^{-5}$ of $\mathrm{R}$ (a: below 20 years, b: $20 \sim 40$ years, c: $40 \sim 60$ years, $\mathrm{d}$ : more than 60 years), the black area represents the exceeding probabilities, and about 73.24, 63.26, 63.47 and $45.74 \%$ for $a, b, c$, and $d$, respectively.

\section{Abbreviations}

BW: body weight; C: concentration of elements; DI: daily intake; ED: exposure duration; EF: exposure frequency; EXPO: exposure to metals; $\mathrm{HQ}$ : hazard quotient; HI: hazard index; MS: morbidity status; ICP-AES: inductively coupled plasma- optical emission spectrometry; I.Q.: Intelligence Quotient;
PTEs: potentially toxic elements; R: carcinogenic risk of As; RfD: reference dose; SF: slope factor; SD: standard deviation; BF: Bioaccumulation factor; USEPA: United States Environmental Protection Agency; WHO: World Health Organization

\section{Acknowledgements}

We would like to express our deepest gratitude to the male and female individuals who participated in the questionnaires of this study. We also thank Professor Caihong Ma form College of Resources and Environmental science, Ningxia University, for the help of using AicGIS Desktop 10 software.

\section{Authors' contributions}

$\mathrm{PL}, \mathrm{MZ}$ and JT conceived and designed the experiments. $\mathrm{YZ}$ and NF performed the experiments. PL and $Y Z$ analyzed the data. JT and $M Z$ provided the analysis tools. PL wrote the manuscript. All authors read and approved the final manuscript.

\section{Funding}

The present study was financially supported by the National Natural Science Foundation of China (grant nos. 21667023 and 51869024) and the Ningxia Key Research and Development Program (grant nos. 2019BFG02020 and 2018BBF02022). The funders played no role in the design of the study and collection, analysis, and interpretation of data and in writing the manuscript.

\section{Availability of data and materials}

The datasets used and/or analysed during the current study available from the corresponding author on reasonable request.

\section{Ethics approval and consent to participate}

The study was approved by the institutional research ethics committee of Ningxia Medical University, and written informed consent was obtained from each participant.

\section{Consent for publication}

Not Applicable.

\section{Competing interests}

The authors declare that they have no conflicts of interest.

\section{Author details}

${ }^{1}$ School of Civil and Hydraulic Engineering, Ningxia University, Yinchuan 750021, China. ${ }^{2}$ School of Physics and Electronic-Electrical Engineering, Ningxia University, Yinchuan 750021, China. ${ }^{3}$ College of Pharmacy, Ningxia Medical University, Yinchuan 750004, China. ${ }^{4}$ College of Basic Medical Sciences, Ningxia Medical University, Yinchuan 750004, China.

Received: 5 June 2020 Accepted: 4 November 2020

Published online: 16 November 2020

\section{References}

1. Qadir M, Wichelns D, Raschid-Sally L, McCornick P, Drechsel P, Bahri A, et al. The challenges of wastewater irrigation in developing countries. Agr Water Manage. 2010;97(4):561-8.

2. Granero S, Domingo J. Levels of metals in soils of Alcalá de Henares, Spain: human health risks. Environ Int. 2002;28(3):159-64.

3. Ministry of Environmental Protection. The communiqué of soil polluted condition investigation. 2014. (in Chinese). http://www.gov.cn/foot/201404/17/content_2661768.htm. Cited 15 May 2020

4. Khan A, Khan S, Khan M, Qamar Z, Waqas M. The uptake and bioaccumulation of heavy metals by food plants, their effects on plants nutrients, and associated health risk: a review. Environ Sci Pollut R. 2015; 22(18):13772-99.

5. Xiao R, Guo D, Ali A, Mi S, Liu T, Ren C, et al. Accumulation, ecologicalhealth risks assessment, and source apportionment of heavy metals in paddy soils: a case study in Hanzhong, Shaanxi. China Environ Pollut. 2019; 248:349-57.

6. LV J, Wang Y. PMF receptor models and sequential Gaussian simulation to determine the quantitative sources and hazardous areas of potentially toxic elements in soils. Geoderma. 2019;353:347-58. 
7. Järup L, Berglund $M$, Elinder $C$, Nordberg G, Vanter M. Health effects of cadmium exposure-a review of the literature and a risk estimate. Scand $J$ Work Env Hea. 1998;24:1-51.

8. Staessen J, Roels H, Emelianov D, Kuznetsova T, Thijs L, Vangronsveld J, et al. Environmental exposure to cadmium, forearm bone density, and risk of fractures: prospective population study. Lancet. 1999;353(9159):1140-4.

9. Järup L, Åkesson A. Current status of cadmium as an environmental health problem. Toxicol Appl Pharm. 2009;238(3):201-8.

10. Srianujata S. Lead-the toxic metal to stay with human. J Toxicol Sci. 1998; 23(Suppl II):237-40.

11. Järup L. Hazards of heavy metal contamination. Brit Med Bull. 2003;68(1):67-182.

12. Abernathy C, Liu Y, Longfellow D, Aposhian H, Beck B, Fowler B, et al. Arsenic: health effects, mechanisms of actions, and research issues. Environ Health Persp. 1999;107(7):593.

13. Mazumder D. Chronic arsenic toxicity \& human health. Indian J Med Res. 2008;128(4):436-47.

14. Adrees M, Ali S, Rizwan M, Ibrahim M, Abbas F, Farid M, et al. The effect of excess copper on growth and physiology of important food crops: a review. Environ Sci Pollut R. 2015;22(11):8148-62.

15. Guertin J. Toxicity and health effects of chromium (all oxidation states). Chromium (VI) Handbook. 2004:215-30.

16. USEPA. Risk-based concentration table. Philadelphia: United States Environmental Protection Agency; 2000

17. Zhang K, Zheng X, Li H, Zhao Z. (2020): Human health risk assessment and early warning of heavy metal pollution in soil of a coal chemical Plant in Northwest China. Soil Sediment Contam 2020. DOI: https://doi.org/10.1080/ 15320383.2020.1746737.

18. Fan X, Mi W, Ma Z, Wang Y. Spatial and temporal characteristics of heavy metal concentration of surface soil in Hebin Industrial Park in Shizuishan Northwest China. Environ Sci. 2013;34(5):1887-94 (in Chinese).

19. Zhang J, Huang W, Martin JM. Trace metals distribution in Huanghe (Yellow River) estuarine sediments. Estuar Coast Shelf S. 1988;26(5):499-516 (in (hinese).

20. Narayan S, Dipak P, Karabi B. Effects of Moringa oleifera lam. And Azadirachta indica a. Juss. Leaf extract in treatment of tannery effluent. Our Nature. 2017;14(1):47-53.

21. Ma X, Zuo H, Liu J, Liu Y. Distribution, risk assessment, and statistical source identification of heavy metals in aqueous system from three adjacent regions of the Yellow River. Environ Sci Pollut R. 2016;23(9):8963-75 (in (hinese).

22. Zhao S, Feng C, Wang D, Liu Y, Shen Z. Salinity increases the mobility of $\mathrm{cd}$, $\mathrm{Cu}$, $\mathrm{Mn}$, and $\mathrm{Pb}$ in the sediments of Yangtze estuary: relative role of sediments' properties and metal speciation. Chemosphere. 2013;91(7):977-84

23. Liu J, Diao Z, Xu X, Xie Q. Effects of dissolved oxygen, salinity, nitrogen and phosphorus on the release of heavy metals from coastal sediments. Sci Total Environ. 2019;666:894-901.

24. Zhang J, Li H, Zhou Y, Dou L, Cai L, Mo L, et al. Bioavailability and soil-tocrop transfer of heavy metals in farmland soils: a case study in the pearl river delta, South China. Environ Pollut. 2018;235:710-9.

25. Antoniadis V, Golia E, Shaheen S, Rinklebe J. Bioavailability and health risk assessment of potentially toxic elements in Thriasio plain, near Athens, Greece. Environ Geochem Health. 2017;39(2):319-30.

26. Cao H, Chen J, Zhang J, Zhang H, Qiao L, Men Y. Heavy metals in rice and garden vegetables and their potential health risks to inhabitants in the vicinity of an industrial zone in Jiangsu, China. J Environ Sci. 2010;22(11): 1792-9.

27. Fountain N. Status epilepticus: risk factors and complications. Epilepsia. 2000;41:S23-30.

28. Hu B, Shao S, Ni H, Fu Z, Hu L, Zhou Y, et al. Current status, spatial features, health risks, and potential driving factors of soil heavy metal pollution in China at province level. Environ Pollut. 2020. https://doi.org/10.1016/j. envpol.2020.114961.

29. Wang S, Cai L, Wen H, Luo J, Wang Q, Liu X. Spatial distribution and source apportionment of heavy metals in soil from a typical county-level city of Guangdong Province. China Sci Total Environ. 2019;655:92-101.

30. Ministry of agriculture of China. Procedural regulations regarding the environment qyality monitoring of water for agricultural use. 2000. NY/ T396-2000. (in Chinese).

31. Ministry of agriculture of China. Procedural regulations regarding monitoring of pullutants in the produces of agriculture, animal husbandry and fishery. 2000. NY/T398-2000. (in Chinese).
32. Ministry of agriculture of China. Technical rules for monitoring of environmental quality monitoring of farmland soil. 2012. NY/T 395-2012. (in Chinese).

33. China standard management committee. Standards for irrigation water quality. 2005. GB 5084-2005 (in Chinese). http://www.gov.cn/fuwu/bzxxcx/bzh.htm. Cited 15 May 2020

34. Vilela S, Severo M, Moreira T, Ramos E, Lopes C. Evaluation of a short food frequency questionnaire for dietary intake assessment among children. Eur J Clin Nutr. 2019;73(5):679-91.

35. USEPA. Guidelines for Exposure Assessment. 1992. Washington DC: U.S. Environmental Protection Agency, Risk Assessment Forum. EPA/600/Z-92/001. https://www.epa.gov/risk/guidelines-exposure-assessment. Cited 15 May 2020.

36. USEPA. Guidance for Performing Aggregate Exposure and Risk Assessments. 1999, Washington DC: U.S. Environmental Protection Agency, Office of Pesticide Programs.

37. USEPA. Guidelines for Carcinogen Risk Assessment, NCEA-F-0644. 2005. Washington DC: U.S. Environmental Protection Agency, Risk Assessment Forum. EPA/630/P-03/001F. https://www.epa.gov/risk/guidelines-carcinogenrisk-assessment. Cited 15 May 2020.

38. Zhu M, Jiang Y, Cui B, Jiang Y, Cao H, Zhang W. Determination of the heavy metal levels in Panax notoginseng and the implications for human health risk assessment. Hum Ecol Risk Assess. 2015;21(5):1218-29.

39. National Food and Drug administration. Limits on contaminants in food in China. GB 2762-2017. (in Chinese).

40. Ministry of agriculture of China. Limits of eight elements in cereal, legume, tubes and its products. 2004. NY 861-2004. (in Chinese).

41. Chinese Environmental Protection Agency. Soil environment quality risk control standard for soil contamination of agriculture land. 2018 GB15618-2018. http://www.gov.cn/fuwu/bzxxcx/bzh.htm (in Chinese). Cited 15 May 2020

42. National Environment Monitoring Station. The background of soil elements in China. China Environmental Science Press; Beijing, China, 1995. (in Chinese).

43. Galal T, Shehata H. Bioaccumulation and translocation of heavy metals by Plantago major L. grown in contaminated soils under the effect of traffic pollution. Ecol Indic. 2015;48:244-51.

44. Satpathy D, Reddy M, Dhal S. Risk Assessment of Heavy Metals Contamination in Paddy Soil, Plants, and Grains (Oryza sativa L.) at the East Coast of India. Biomed Res Int. 2014;2014(3-4):545473.

45. Yang $X, L i$ Y, Ma G, Xiao Q, Wang J. Study on weight and height of the Chinese people and the differences between 1992 and 2002. Chinese J Epidemiology. 2005;26:489-93 (in Chinese).

46. JECFA (joint FAOMHO expert committee on food additives). Evaluation of certain food additives and contaminants: 41st report of JECFA. Technical reports series no.837. 1993. Geneva: World Health Organization.

47. El-Hassanin A, Samak M, Abdel-Rahman G, Abu-Sree Y, Saleh E. Risk assessment of human exposure to lead and cadmium in maize grains cultivated in soils irrigated either with low-quality water or freshwater. Toxicol Rep. 2020;7:10-5.

48. Farahat E, Galal T, Elawa O, Hassan L. Health risk assessment and growth characteristics of wheat and maize crops irrigated with contaminated wastewater. Environ Monit Assess. 2017;189:535.

49. Cao L, Lin C, Gao Y, Sun C, Xu L, Zheng L, et al. Health risk assessment of trace elements exposure through the soil-plant (maize)-human contamination pathway near a petrochemical industry complex, Northeast China. Environ Pollut. 2020;263:114414.

50. Zheng N, Wang Q, Zhang X, Zheng D, Zhang Z, Zhang S. Population health risk due to dietary intake of heavy metals in the industrial area of Huludao city, China. Sci Total Environ. 2007;387(1-3):96-104.

51. Jiang M, Jiang Y, Xu J, Guo S. Distribution characteristics of heavy metals in maize plants and their cultivated land. Heilongjiang Agricultural Science. 2018:5:116-20 (in Chinese).

52. Hu B, Jia X, Hu J, Xu D, Xia F, Li Y. Assessment of heavy metal pollution and health risks in the soil-plant-human system in the Yangtze River Delta, China. Int J Env Res Pub He. 2017;14(9):1042.

53. Wang S, Wu W, Liu F, Liao R, Hu Y. Accumulation of heavy metals in soilcrop systems: a review for wheat and corn. Environ Sci Pollut R. 2017;24(18): $15209-25$.

54. Hu B, Xue J, Zhou Y, Shao S, Fu Z, Li Y, et al. Modelling bioaccumulation of heavy metals in soil-crop ecosystems and identifying its controlling factors using machine learning. Environ Pollution. 2020;262:114308. 
55. Yousaf B, Liu G, Wang R, Rehman M, Rizwan M, Imtiaz M, et al. Investigating the potential in-fluence of biochar and traditional organic amendments on the bioavailability and transfer of $\mathrm{cd}$ in the soil-plant system. Environ Earth Sci. 2016:75:1-10.

56. Zhao F, Ma Y, Zhu Y, Tang Z, McGrath S. Soil contamination in China: current status and mitigation strategies. Environ Sci Technol. 2015;49(2):750-9.

57. Zhang X, Yang H, Cui Z. Evaluation and analysis of soil migration and distribution characteristics of heavy metals in iron tailings. J Clean Prod. 2018;172:475-80

58. Hu B, Li J, Bi N, Wang H, Yang J, Wei H, et al. Seasonal variability and flux of particulate trace elements from the Yellow River: impacts of the anthropogenic flood event. Mar Pollut Bull. 2015;91(1):35-44.

59. Yu R, Wang Y, Wang C, Yu Y, Cui Z, Liu J. Health risk assessment of heavy metals in soils and maize (Zea mays L.) from Yushu, Northeast China. Hum Ecol Risk Assess. 2017:23(6):1493-504.

60. Mao C, Song Y, Chen L, Ji J, Li J, Yuan X, et al. Human health risks of heavy metals in paddy rice based on transfer characteristics of heavy metals from soil to rice. Caten. 2019;175:339-48.

61. Li L, Feng H, Wei J. Toxic element (as and hg) content and health risk assessment of commercially available rice for residents in Beijing based on their dietary consumption. Environ Sci Pollut Res. 2020;27:13205-14.

62. Chanpiwat P, Kim K. Arsenic health risk assessment related to rice consumption behaviors in adults living in northern Thailand. Environ Monit Assess. 2019;191:674.

63. Jiang $Y$, Zeng $X$, Fan $X$, Chao S, Zhu M, Cao H. Levels of arsenic pollution in daily foodstuffs and soils and its associated human health risk in a town in Jiangsu Province, China. Ecotox Environ Safe. 2015;122:198-204.

64. Cai L, Xu Z, Qi J, Feng Z, Xiang T. Assessment of exposure to heavy metals and health risks among residents near Tonglushan mine in Hubei, China. Chemosphere. 2015;127:127-35.

65. Sawut R, Kasim N, Maihemuti B, Hu L, Abliz A, Abdujappar A, et al. Pollution characteristics and health risk assessment of heavy metals in the vegetable bases of Northwest China. Sci Total Environ. 2018:642:864-78.

\section{Publisher's Note}

Springer Nature remains neutral with regard to jurisdictional claims in published maps and institutional affiliations.

Ready to submit your research? Choose BMC and benefit from:

- fast, convenient online submission

- thorough peer review by experienced researchers in your field

- rapid publication on acceptance

- support for research data, including large and complex data types

- gold Open Access which fosters wider collaboration and increased citations

- maximum visibility for your research: over $100 \mathrm{M}$ website views per year

At $\mathrm{BMC}$, research is always in progress.

Learn more biomedcentral.com/submissions 